\title{
Analysis of Air Conditioning Arrangement for Two Floor Shopping Complex by using Revit MEP Software
}

\author{
S. Visweswara Rao', Badisha Gopi' ${ }^{2}$, Aggidi Harish², Boda Sumanth ${ }^{2}$ \\ ${ }^{1}$ Assistant Professor, ${ }^{2}$ Student \\ 1,2Department of Mechanical Engineering, Guru Nanak Institute of Technology, Hyderabad, India
}

\begin{abstract}
How to cite this paper: S. Visweswara Rao | Badisha Gopi | Aggidi Harish | Boda Sumanth "Analysis of Air Conditioning Arrangement for Two Floor Shopping Complex by using Revit MEP Software" Published in International Journal of Trend in Scientific Research and Development (ijtsrd), ISSN: 2456-

6470, Volume-3 | Issue-3 , April 2019, pp.1065-1068, URL: https://www.ijtsrd.c om/papers/ijtsrd23 257.pdf

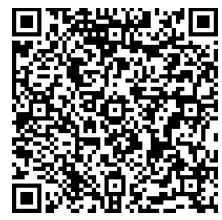
IITSRD23257

Copyright (C) 2019 by author(s) and International Journal of Trend in Scientific Research and Development Journal. This is an Open Access article distributed under the terms of the Creative Commons Attribution License (CC BY 4.0) (http://creativecommons.org/licenses/ by $/ 4.0$ )
\end{abstract}

\section{INTRODUCTION}

In present era population rapidly increasing as the population increases their rate of needs also increases, everyone wants comfort life like comfortness in their daily activities and they need comfortable environments like enough light, air and water. Because of environmental changes only people need comfort life as the environment changes from one state to other they need comfortness as with respect to environment.

In case of comfrtness related to light is easy to maintain compared to others like air and water, by using electricity we can maintain intensity of light in houses and buildings etc. Water needs also maintained by borewells, rivers and oceans for small to large application purposes. But it is some what difficult to maintain air quality and humidity in air even though this problem is solved by invention of refrigeration and air conditioning systems. These systems provide cooling and heating effects according to customers choices.

Different air conditioning (AC) systems are there like split and window AC systems these are generally used for small load applications like offices and small rooms and houses etc. For large scale industries and high load application these systems are not suitable for this purpose heating, ventilation and air conditioning systems are invented (HVAC). Human body comfortable at $22 \square-25 \square$, if temperature in atmosphere is below and above to this temperature human feels uncomfortable, in order to solve this problem HVAC systems are employed.

HVAC system installed to achieves environmental requirements of comforts of occupants present in that place where system is installed, and the main aim of this system is to provide thermal comfortness to occupants. This can be done by changing outdoor air conditions to desired air condition of the occupants, depending upon outdoor quality of air indoor air quality is modified or conditioned on basic of choice of occupants in that place where HVAC system is installed to maintain air conditioning process of that area.

In general like in split and window Ac systems cooled air is directly distributed to surroundings from air conditioning systems, there is no intermediate equipment or device in order to transfer cooled air from system to surrounding because capacity of this type of systems is limited to small amount of load only. But in case of large load applications like commercial buildings and institutional buildings etc they need intermediate device to transfer cooled air from air 
conditioning system to surroundings (different portions of buildings). This device is called duct which is used to supply cold air and extract hot air from surroundings, and it is used to recirculation purpose.

Installation or selectin of HVAC system depends on following parameters or factors like climate conditions, building design, building age, project budget and owner preferences as shown in Fig.1.

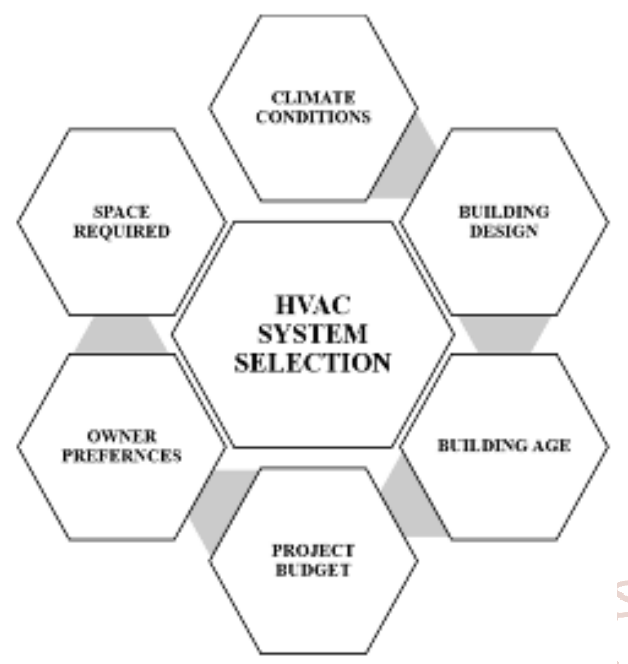

Fig.1. System Selection Factors

In this project for designing and analysing AC setting for two floor shopping complex Autodesk Revit MEP software is used, it is building information modelling software. The main features of this software are accurate design, documentation within in a short span of time and one of the best features is that if one part is modified with respect to its other parts also modified it increases productivity of design.

HVAC systems are broadly classified as four categories, they are all air systems, all water system, air-water systems and unitary systems. Unitary systems used where low cost is taken as budget of project, for control of humidity all air systems used, large exposure purpose air-water systems are employed, and all water systems are employed for limited space and existing buildings [1]. Various uncertainties are to be considered in case of methodology of primary HVAC systems these must be optimized in order to get good results [2]. Chiller and heater in HVAC systems (Theatre) are consuming more energy due to this energy scarcity occurs to the system in order to overcome this problem heating devices are replaced with condenser of heat pipe heat exchangers [3].

Subspace identification technique is used to model thermodynamics of each zone independently in order to do thermal predictions [4]. Minimization of energy consumption takes place in HVAC systems by replacing Nonrenewable energy sources with renewable energy sources [5].

\section{METHODOLOGY}

Methodology for this project involves different stages as shown in Fig.2. like space available for system arrangement and installation, duct design for the shopping complex and cooling and heating load calculations. These are the major stages involved in this project, first of space need to consider like two floor shopping complex floor wise area and number of sections in it. Duct arrangement design on basis of number of workspaces in complex, finally cooling and heating load condition on basis of factors as shown in Fig.3. like occupancy, occupants load, Building thermal load, Light and power supply load and air for ventilation purpose.

In order to calculate cooling and heating loads for any building first occupants load and thermal loads involves inside building is calculated.

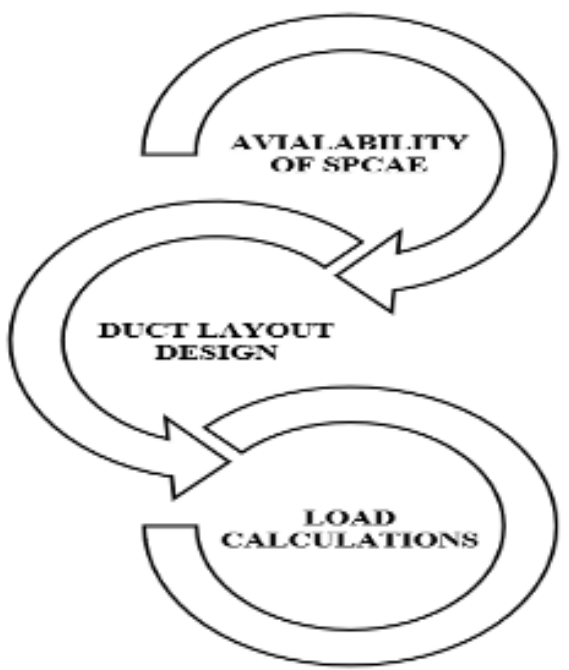

Fig.2. Stages of HVAC System Design in Complex

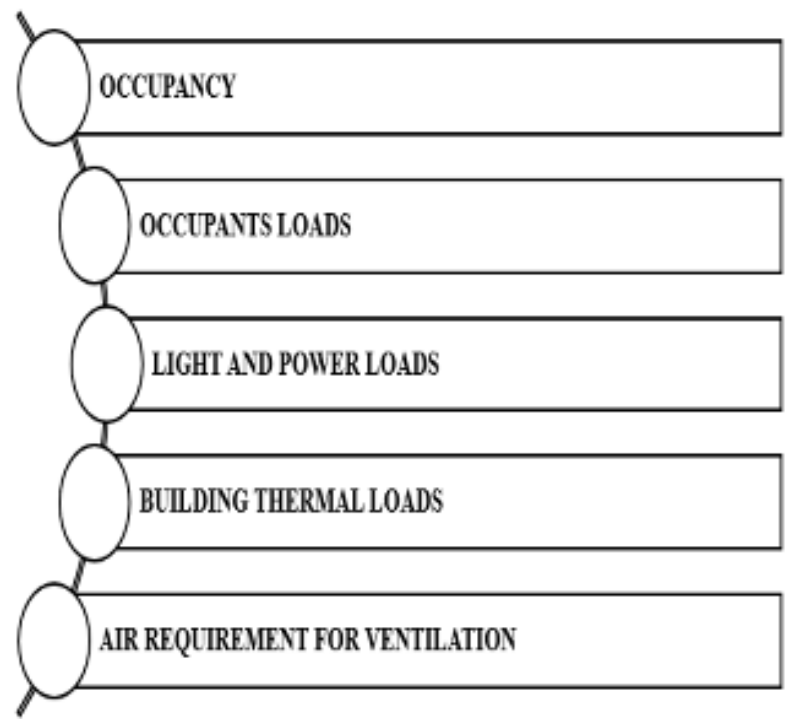

Fig.3. Parameters for Load Calculations

III. AIR-CONDITIONING SYSTEM DESIGN FOR Two FLOORS This project involves air conditioning system design and analysis for two floor shopping complexes, for this purpose individually load calculations are to be done for first as well as second floors. In general floor to floor work spaces are different compared to other floors so individual calculations are required.

In order to design duct arrangements for two floors Revit software is used, it gives information and documentation about building in design process, design procedure for two floors as discussed below

$>$ First draw a rectangle (with building area) and then divide the sections in it these are the room in that floor and create windows. In this step floor layouts are created as shown in Fig.4. and Fig.5. 


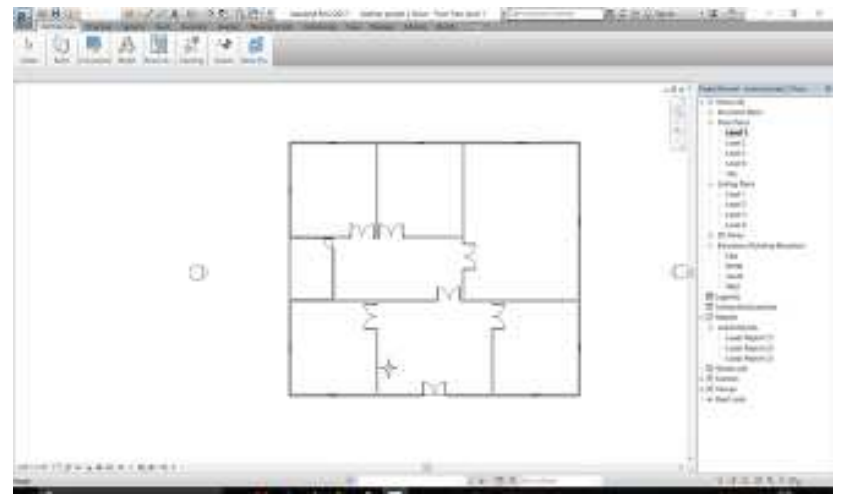

Fig.4. First Floor Layout

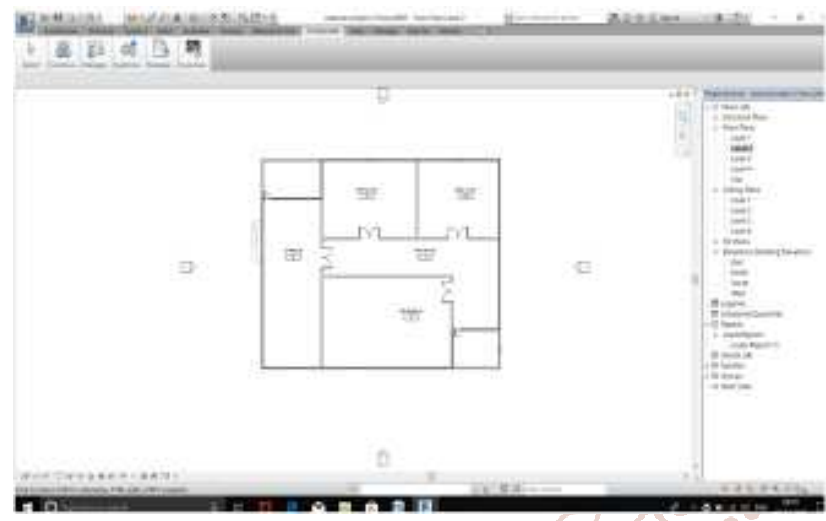

Fig.5. Second Floor Layout

$>$ After layout, ceiling drawings and duct arrangements for rooms depends on their load capacity are drawn as shown in Fig.6. and Fig.7.

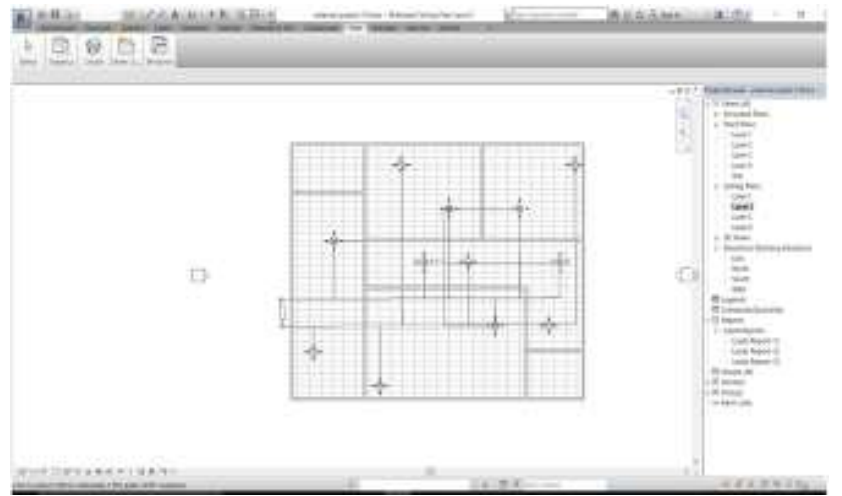

Fig.7. Second Floor Ceiling with Duct Layout

$>$ Create spacing and zoning for different workspaces in two floors as shown in Fig.8. and Fig.9.

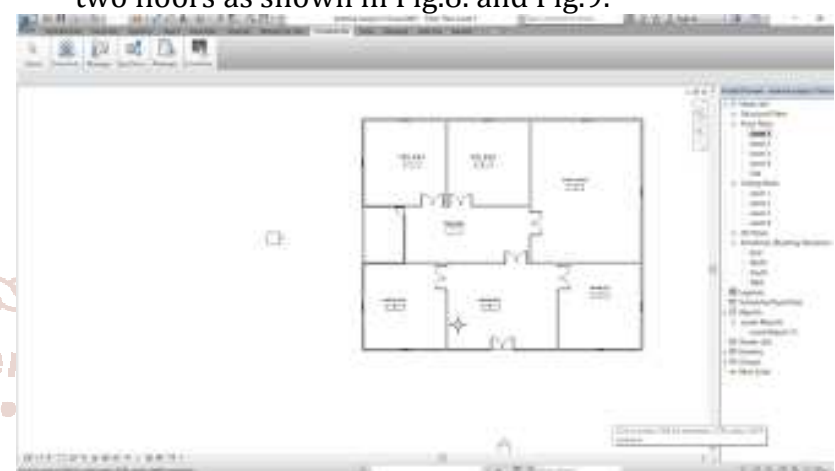

Fig.8. First Floor Spacing and Zoning

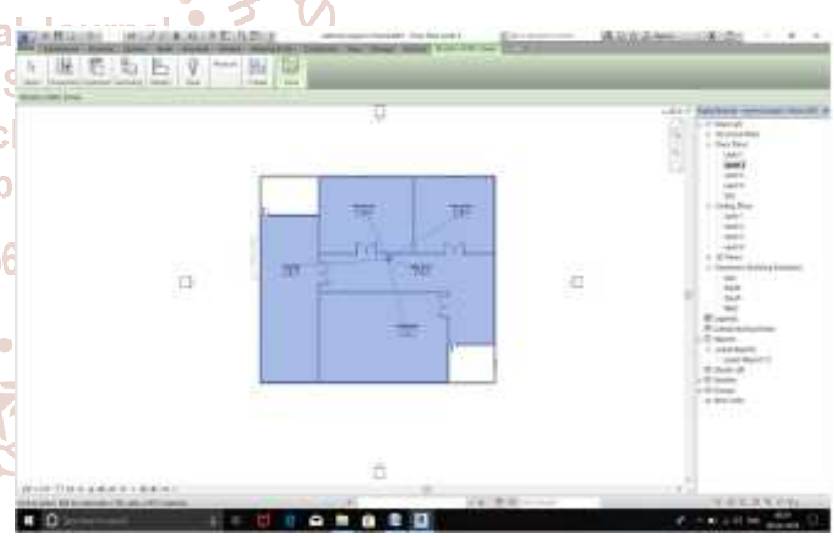

Fig.9. Second Floor Spacing and Zoning

$>$ After creation of duct arrangement by using analyse option get the load reports for floors.

Fig.6. First Floor Ceiling with Duct Layout

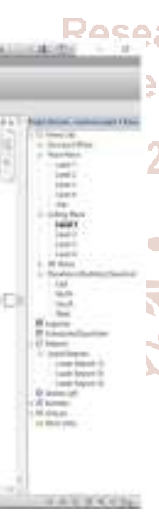

(20)

\section{RESULTS AND DISCUSSION}

Cooling and heating loads are calculated on basis of different parameters involved in calculations, for two different floors individually loads are calculated results are listed in Table I. and Table II, building summary mentioned in Table III, these are all generated in Revit software.

These tabulated results are automatically generated by Revit software by entering input values related to building and individual floor number of workspaces and areas, volumes of different workspaces in two floor shopping complexes

\begin{tabular}{|c|c|c|c|c|c|c|}
\hline Space Name & $\begin{array}{c}\text { Area } \\
\text { (SF) }\end{array}$ & $\begin{array}{c}\text { Volume } \\
\text { (CF) }\end{array}$ & $\begin{array}{c}\text { Peak Cooling } \\
\text { Load (Btu/h) }\end{array}$ & $\begin{array}{c}\text { Cooling Airflow } \\
\text { (CFM) }\end{array}$ & $\begin{array}{c}\text { Peak Heating } \\
\text { Load (Btu/h) }\end{array}$ & $\begin{array}{c}\text { Heating Airflow } \\
\text { (CFM) }\end{array}$ \\
\hline WORK SPCAE-1 & 860 & $7,744.00$ & $65,035.2$ & 3,418 & $-2,431.3$ & 489 \\
\hline WORK SPCAE-2 & 860 & $7,744.00$ & $63,887.8$ & 3,358 & $-3,195.1$ & 443 \\
\hline WORK SPCAE-3 & 1,940 & $17,464.00$ & $142,222.0$ & 7,476 & $-6,081.7$ & 1,006 \\
\hline MANAGER & 860 & $7,744.00$ & $62,754.6$ & 3,299 & -656.9 & 474 \\
\hline RECEPTION & 1,154 & $10,384.00$ & $83,349.5$ & 4,381 & $-2,656.6$ & 609 \\
\hline ACCOUNTS & 860 & $7,744.00$ & $67,035.7$ & 3,522 & $-4,420.2$ & 489 \\
\hline CORRIDOR & 857 & $7,714.00$ & $61,440.3$ & 3,230 & $-1,220.8$ & 438 \\
\hline
\end{tabular}


International Journal of Trend in Scientific Research and Development (IJTSRD) @ www.ijtsrd.com eISSN: 2456-6470

Table II: Second Floor Load Values

\begin{tabular}{|c|c|c|c|c|c|c|}
\hline Space Name & Area (SF) & $\begin{array}{c}\text { Volume } \\
\text { (CF) }\end{array}$ & $\begin{array}{c}\text { Peak Cooling } \\
\text { Load (Btu/h) }\end{array}$ & $\begin{array}{c}\text { Cooling } \\
\text { Airflow (CFM) }\end{array}$ & $\begin{array}{c}\text { Peak Heating } \\
\text { Load (Btu/h) }\end{array}$ & $\begin{array}{c}\text { Heating } \\
\text { Airflow (CFM) }\end{array}$ \\
\hline CORRIDOR & 1,565 & $14,089.00$ & $113,011.4$ & 5,905 & -782.4 & 862 \\
\hline WORK SPCAE-9 & 1,154 & $10,384.00$ & $84,277.3$ & 4,404 & $-2,772.5$ & 604 \\
\hline WORK SPCAE-10 & 1,007 & $9,064.00$ & $74,662.5$ & 3,901 & $-2,574.9$ & 545 \\
\hline WORK SPCAE-11 & 1,452 & $13,069.00$ & $104,852.5$ & 5,479 & $-2,479.2$ & 756 \\
\hline CONFERENCE HALL & 1,865 & $16,789.00$ & $148,631.1$ & 7,755 & $-18,361.3$ & 953 \\
\hline
\end{tabular}

Table III: Building Summary

\begin{tabular}{|c|c|}
\hline Inputs & \\
\hline Building Type & Office \\
\hline Area (SF) & 14,437 \\
\hline Volume (CF) & $129,933.00$ \\
\hline Calculated Results & \\
\hline Peak Cooling Total Load (Btu/h) & $\mathbf{1 , 1 0 2 , 3 4 6 . 0}$ \\
\hline Peak Cooling Month and Hour & April 13:00 \\
\hline Peak Cooling Sensible Load (Btu/h) & $1,071,376.0$ \\
\hline Peak Cooling Latent Load (Btu/h) & $30,970.0$ \\
\hline Maximum Cooling Capacity (Btu/h) & $1,102,346.0$ \\
\hline Peak Cooling Airflow (CFM) & 56,128 \\
\hline Peak Heating Load (Btu/h) & $\mathbf{- 4 7 , 6 3 3 . 1}$ \\
\hline Peak Heating Airflow (CFM) & 7,668 \\
\hline Checksums & \\
\hline Cooling Load Density (Btu/(h.ft ${ }^{2}$ )) & 76.36 \\
\hline Cooling Flow Density (CFM/SF) & 3.89 \\
\hline Cooling Flow / Load (CFM/ton) & 611.00 \\
\hline Cooling Area / Load (SF/ton) & 157.16 \\
\hline Heating Load Density (Btu/(h.ft ${ }^{2}$ )) & -3.30 \\
\hline Heating Flow Density (CFM/SF) & 0.53 \\
\hline
\end{tabular}

\section{CONCLUSION}

HVAC system setting for two floor shopping complex gives different conclusion in case of loads of two individual floors, cooling and heating air flows as discussed below

$>$ Peak cooling and heating loads for two floor shopping complexes are different for individual floors, second floor require more load even though it is having less workspaces.

$>$ Cooling air flow requirement for first floor is less compared to second floor because of low peak heating loads of first floor.

$>$ Heating air flow is more in first floor compared to second floor because of peak cooling load is less in first floor.

$>$ Load requirements are not depending on number of workspaces it depends on capacity of workspace and occupancy capacity of it.

\section{ACKNOWLEDGMENT}

I owe my immense thanks to my project Guide $\mathbf{S}$. VISWESWARA RAO, Assistant professor DEPARTMENT OF MECHANICAL ENGINEERING Guru Nanak Institute of Technology for this sustained interest, constructive criticism and constant encouragement at every stage of this Endeavour.

Also, I heart fully thank Dr. B. Vijaya Kumar, professor and head of department, Guru Nanak Institute of Technology for his constant encouragement.

I extended my deep sense of gratitude to the principle Dr. S. Sreenatha Reddy and the management of Guru Nanak Institute of Technology for providing of the best amenities to enable us to complete my project in stipulated time.

\section{REFERENCES}

[1] S. M. Gheji, K. S. Kamble and A. A. Gavde "Basic Classification of HVAC system for Selection Guide" International Journal of Innovative Research in Science, Engineering and Technology Vol. 5, No. 4, 2016, pp. 6077-6086.

[2] Harkamaljeet Singh Bhullar and Vikram Kumar Kamboj "Energy conservation of heat, ventilation \& Air Conditioning System with the Help of Fuzzy Controllers" International Journal of Scientific \& Engineering Research Vol. 2, No. 10, 2011, pp. 1-8.

[3] Mohammad Ahmadzadehtalatapeh "Improving the Energy Performance of HVAC System Operating Theatres by Using Heat Recovery Devices" International Journal of Renewable Energy Research Vol. 4, No. 3, 2014, pp. 587-593.

[4] O. Tsakiridis, D. Sklavounos and E. Zervas "A Comfortaware Energy HVAC System Based on Subspace Identification Method" Journal of Energy Vol. 2016, pp. 1-13.

[5] Arsha Viswambharan, Sheetal Kumar Patidar and Khyati Saxena "Sustainable HVAC Systems in Commercial and Residential Buildings International Journal of Scientific and Research Publication Vol. 4, No. 4, 2014, pp. 1-4. 